tilganger. Hoveddelen omfatter 150 større og mindre inngrep og prosedyrer ordnet etter organsystem: hud og bløtvev, hals, thorax, abdomen, retroperitoneum og ytre genitalia. Emner som brokk, barnekirurgi, karkirurgi og amputasjoner er også dekket. Kapitlet om traumatologi er rent ortopedisk rettet og inkluderer håndtering av septisk gonartritt og operasjon ved Dupuytrens kontraktur og karpaltunnelsyndrom.

Utvalget av prosedyrer virker litt vilkårlig, og spennet er stort, fra incisjon av paronyki til anatomisk lungereseksjon, leverreseksjon og rectumreseksjon. De sistnevnte står ikke på utdanningsrepertoaret til dagens norske kandidater innen generell kirurgi. Enkelte inngrep, for eksempel selektiv proksimal eller trunkal vagotomi og Bassinis plastikk ved lyskebrokk er nå lite aktuelle. Utvalget av torako-laparoskopiske prosedyrer er meget begrenset. Kirurgi ved tykktarmskreft eller ventralhernier er for eksempel kun beskrevet med åpen tilgang.

Hvert inngrep er beskrevet trinnvis i ti punkter: indikasjon, preoperative forberedelser, pasientinformasjon, anestesi, leiring, tilgang, operasjonsteknikk, anatomi, håndtering av spesielle komplikasjoner og postoperativ behandling. Den skjematiske fremstillingen er oversiktlig, men medfører også oppramsing av en del selvfølgeligheter.

Den anbefalte litteraturen er rundt 20 år gammel, og dette gjenspeiles i teksten.

Ved hemikolektomi anbefales preoperativ tarmtømming, postoperativ nasogastrisk sonde og abdominaldren $\mathrm{i}$ henholdsvis 1-3 og 7-8 dager. Små slurker klar væske tillates fra 3.-4. dag, fast føde etter første avføring, rundt 7. dag. Eksemplet illustrerer hvor vanskelig det er å innføre moderne prinsipper for perioperativ behandling. Tarmanastomoser anlegges med avbrutte fullveggssuturer. Trådvalget omfatter kromcatgut og silke. Ved «gastric outlet obstruction» nevnes ikke endoskopisk stent-behandling som et alternativ, og intervensjonsradiologi er ikke nevnt som en mulighet ved blødende peptisk ulcus.

Dette er et verk i stort format, solid innbundet og på godt papir. De 1223 illustrasjonene er i svart-hvitt og av varierende kvalitet. Enkelte komplekse prosedyrer, som lungereseksjoner, illustreres så knapt og overfladisk at det ikke er til hjelp. Andre inngrep, for eksempel ved lyskebrokk, er bedre beskrevet.

Forfatteren, professor Schumpelick, er sjef for kirurgisk avdeling ved universitetssykehuset i Aachen, president i den tyske kirurgiske forening, lærebokforfatter og en nestor i tysk kirurgi. Atlas of general surgery er utgitt på Thieme, et kvalitetsforlag for medisinsk litteratur. Resultatet er skuffende.

\section{Introduksjon til stråleterapi}

Degerfält J, Moegelin I-M, Sharp L. Strålbehandling

276 s, tab, ill. Lund: Studentlitteratur, 2009 Pris SEK 331

ISBN 978-91-44-04523-8

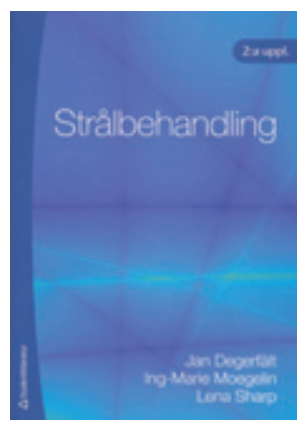

Onkologi som selvstendig spesialitet (terapeutisk onkologi og stråleterapi) ble opprettet i 1964. Spesialiteten sprang ut fra diagnostisk radiologi, der man inntil da hadde tatt hånd om stråleterapi av benigne

så vel som maligne lidelser. Behovet for en egen spesialitet meldte seg etter hvert som det medikamentelle tilbud til kreftpasienter økte. Spesialiteten skiftet navn til onkologi i 1991 og omfatter både stråleterapi og medikamentell behandling av kreft. I en del andre land er dette separate spesialiteter.

Utviklingen innen medisinsk bildediagnostikk de siste tiår har vært enorm. Dette, sammen med utviklingen av datateknologien, har spesielt kommet kreftbehandlingen til gode ved at presisjonsnivået for stråleterapi har økt betraktelig. Stråling avleveres nå med millimeters nøyaktighet i forhold til målvolumet.

Stråleterapi er en tverrfaglig aktivitet som fordrer tett samarbeid mellom sykepleiere, stråleterapeuter, fysikere, radiologer og onkologer. Førsteforfatteren er stråleterapeut og adjunkt ved Lunds universitet, avdelingen for onkologi. De to andre forfattere er sykepleiere med årelang klinisk og pedagogisk erfaring innen kreftomsorg.

Dette er en kortfattet lærebok i stråleterapi. Språket er svensk, formatet hendig og innbindingen robust (paperback) utmerket egnet til å slå opp i for sykepleiere på post. Illustrasjonene er enkle og tjener som et godt supplement til teksten. Bakerst er det illustrerende fotografier.

Den er tredelt: I kapittel 1-7 tar man for seg fysiske og tekniske aspekter vedrørende stråleterapi, i kapittel 8 er det strålebiologi og i kapittel 9-18 pleiemessige forhold under og etter stråleterapi. Jeg synes forfatterne har fătt med seg det viktigste rundt stråleterapiprosessen, om enn meget kortfattet. Noen begreper blir hengende i luften, men det er rikelig med relevante referanser. Dette er 2. utgave, jeg synes faktisk 1. utgave var mer utfyllende på dette området. Strålebiologien er greit ivaretatt, særlig fraksjonering. I siste del omhandles psykososiale forhold og bivirkninger ved strålebehandling og håndtering av dette. Her finnes mye nyttig informasjon til bruk i den kliniske hverdag, og det er rikelig med henvisninger til oppdatert relevant litteratur.
Samlet sett er dette en god introduksjon til stråleterapi, godt egnet for sykepleiere som tar hånd om pasientene under og etter behandlingen. Den passer også utmerket for medisinstudenter som vil sette seg inn i stråleterapien, et fag jeg for øvrig har inntrykk av har for liten plass i det medisinske studium. Stråleterapeuter vil særlig ha nytte av siste tredel. For fysikere og onkologer er imidlertid Strålbehandling til relativt liten nytte, den er for elementær til det.

\section{Jan Folkvard Evensen}

Kreftklinikken

Oslo universitetssykehus, Rikshospitalet

\section{Hjemmetjenestene - små fakta om store problemer}

\author{
Verdens helseorganisasjon \\ Home care in Europe \\ 36 s, tab, ill. København: WHO, 2008. \\ Pris CHF 10
}

ISBN 978-92-890-4281-9

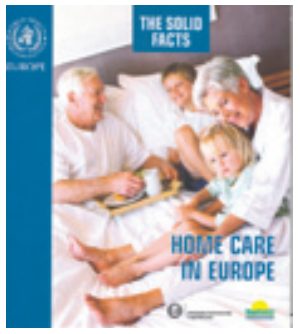

«Overtittelen»på denne lille utgivelsen om hjemmetjenester i Europa er «The solid facts». Den er utgitt av Europakontoret til Verdens helseorganisasjon og Bocconi

University i Milano. Det er mange bidragsytere fra flere europeiske land, men ingen fra de nordiske landene.

Man starter med å slå fast at behovet for hjemmetjenester øker i alle land pga. eldrebølgen og fordi det blir flere mennesker med kroniske sykdommer. Det er fire kapitler: oversikt over hjemmetjenestene i Europa, de økende behovene, tilbudssiden og utfordringene for politikk og administrasjon. Teksten er grei nok, det er eksempler fra mange av landene (i små rammer med liten skrift) og noen få, delvis uleselige figurer.

Forfatterne drøfter de økende utfordringene: stadig større behov, for lite ressurser, dårlig samarbeid mellom spesialisthelsetjenesten og hjemmetjenestene (noe som fører til svingdørspasienter ved sykehusene og forsømte pasienter i hjemmene) og dårlig kommunikasjon. I alle land forsøker man å mobilisere til mer innsats fra de pårørende og å utvikle alle slags «lure løsninger» for fordeling av ansvar og kostnader. Jeg leser alt dette med et sukk - dels fordi så mange pårørende enten er døde eller har flyttet, dels fordi det ikke finnes hemmelige triks. Man kan tro på konkurranseutsetting og «co-payment» og overlate ansvaret til den enkelte, eller man kan tro på full dekning fra det offentlige. Men problemene er hele 
tiden: økende behov, mer komplekse behov, vanskelig tverrfaglig samhandling, for lite penger, for få hjelpere, svart arbeid, innvandrere med dårlige språkkunnskaper osv. To tall gjør inntrykk: Spania bruker $0,2 \%$ av bruttonasjonalproduktet på hjemmetjenester, Sverige 2,75\%.

Teksten er ikke lettlest. Den beskriver situasjonen og de valgte løsningene i de europeiske land (det er lite om de nordiske land). Jeg savner statistisk dokumentasjon, og jeg føler at denne utgivelsen er altfor liten til dette store problemet. Den kan selvfølgelig ikke tilby de geniale løsningene. De ligger kanskje et sted mellom Ronald Reagans «The state is not the solution. It is the problem!» og Fjodor Dostojevskijs «Vi har alle ansvar for hverandre!».

Home care in Europe har størst interesse for politikere og for administrative ledere i departementer, direktorater og kommuner, men jeg er redd de ikke vil finne løsningene på utfordringene i hjemmetjenesten her.

Peter F. Hjort

Blommenholm

\section{Teoretisk om påvirkning av atferd}

Elliott $P$, red.

Infection control

A psychosocial approach to changing practice.

264 s, tab, ill. Oxon: Radcliffe, 2009. Pris GBP 25

ISBN 978-1-85775-612-8

Hygieniske standardtiltak er grunnleggende for å forebygge sykehusinfeksjoner og samtidig verne personalet mot smitte. Til tross for god kunnskap om effekten av smitteforebygging er det bredt dokumentert at helsepersonell ikke alltid utfører slike tiltak i overensstemmelse med gjeldende retningslinjer. Tradisjonelt har man brukt undervisning, retningslinjer, gjennomføring av kvalitetskontroll og infeksjonsovervåking for å bedre helsepersonells smitteforebyggende atferd. I boken presenteres nye tilnærmingsmåter for å påvirke atferden ved å vektlegge hvordan psykososiale mekanismer influerer på enkeltindividers og gruppers handlingsmønstre. Målgruppen er helse- og sosialarbeidere.

Infection control er inndelt i to seksjoner. I den første introduseres biomedisinske og biopsykososiale modeller og teorier, og disse relateres til utøvelse av hygieniske standardtiltak. I del 2 reflekteres det over hvorfor det er vanskelig å påvirke atferd og hvilke tilnærminger som kan bedre smitteforebyggingen.

Gjennom hele boken er det ulike refleksjonsoppgaver. Oppgavene er bokens styrke og utfordrer leserens egen smitteforebyggende atferd og oppfatninger om infek- sjonsforebyggende retningslinjer. Oppgavene kan med fordel benyttes i undervisning, gruppearbeid og kvalitetsforbedring.

Referanser, definisjoner, liste over standardtiltak og oppskrift på håndvask repeteres når nye emner introduseres. Repetisjonene gjør det lettere å tilegne seg de kompliserte biomedisinske og biopsykososiale teoriene, men bidrar samtidig til at leseren kan få en følelse av manglende progresjon.

For å gjøre teoriene mer oversiktlige benyttes figurer og tabeller. Når teoriene relateres til tilfredsstillende eller manglende smitteforebyggende atferd, som i kapittel 4 , er det vanskelig å følge forfatterens tankegang. Utdypende eksempler fra klinisk praksis for å belyse de ulike teoriene ville sannsynligvis bidratt til å gjøre disse mer tilgjengelige for leseren.

Forhold som bidrar til å redusere forfatterens troverdighet er hans beskrivelse av god håndhygiene, som fraviker fra Nasjonal veileder for håndhygiene, CDCs Guideline for Hand Hygiene in Healthcare Settings og National Health Services (NHS) Guidelines for preventing healthcare-associated infections. Forfatterens tolking av modellen «smittekjeden», som beskriver hvordan infeksjonssykdommer oppstår og videreføres, er direkte feil. Han hevder at modellen er utdatert - med den begrunnelse at den aldri har bidratt til å bedre sykehushygienisk atferd.

Innholdet fremstilles svært teoretisk, og det synes å være vanskelig å omsette teoriene i praktisk handling.

\section{Anne Dalheim}

Senter for smittevern

Helse Bergen

\section{Exit artrose}

Bales $P$

\section{Osteoarthritis}

Preventing and healing without drugs. 284 s, ill. Amherst, NY: Prometheus Books, 2008. Pris USD 19

ISBN 978-1-59102-615-0

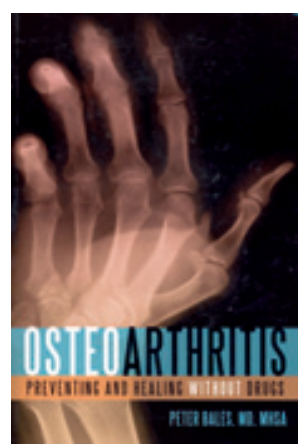

Umiddelbart syntes jeg det var noe pretensiøst å gi en bok en tittel som tilsier at den er nøkkelen til å helbrede artrose. Forfatteren er ortoped, men er opptatt av ernæring og påberoper seg en holistisk tilnærming til artrose. Det er noe overraskende at ortopedisk behandling ikke tillegges noen betydning.
Det påstås i forordet at leger ikke tar $\mathrm{i}$ bruk ny kunnskap i hverdagen når $\mathrm{de}$ behandler pasienter med artrose, og forfatteren etterlyser en holistisk tilnærming til artrose hos oss leger. Som revmatolog med spesiell interesse for artrose synes jeg at det loves for mye i boken, siden kunnskapsgrunnlaget for denne type behandling av artrose ikke er stort. Slik sett er jeg nok faglig uenig med forfatteren, og dette svekker min begeistring for boken.

Forskning innenfor ernæring og kosttilskudd generelt, og særlig i relasjon til artrose, får mye plass. I flere deler belyses artrosens samfunnsmessige betydning og hvilke metabolske tilstander som predisponerer for tilstanden, inklusive insulinresistens og oksidativt stress. Målgruppen er hovedsakelig legfolk, og forfatteren forklarer basale emner, f.eks. DNA, og belyser så noen genetiske aspekter. En rekke studieresultater gjennomgås, og til slutt kommer forfatteren med personlige anbefalinger av inntak av en lang liste vitaminer og ernæringstilskudd.

Noen ganger blir man forvirret av det varierende presisjonsnivået. Den helsemessige betydningen av insulinresistens, metabolsk syndrom og overvekt kobles etter mitt syn for raskt til selve artrosesykdommen, og det tegnes generelt et optimistisk bilde av effekten av kosttilskudd, noe som står i kontrast til gjeldende kunnskapsgrunnlag. Studier som viser negativ effekt, for eksempel ved glukosamin og kondroitin, trekkes generelt ikke frem. Forfatteren skal likevel ha honnør for å komme med en rekke relevante referanser til anerkjente medisinske fagtidsskrifter som belyser ikke-medikamentelle aspekter som ellers sjelden trekkes frem.

Hans hovedkonklusjon er at interaksjon mellom næringsstoffer og inflammasjon åpner for behandling av artrose. For håpe at han har rett i det. Hadde boken vært min hovedkilde til informasjon om artrose, hadde jeg blitt begeistret og kjøpt kosttilskudd i håp om å skåne mine ledd. Men det gjør jeg ikke. Boken er ikke balansert og kan ikke anbefales for leger som ønsker å sette seg inn i behandlingsmuligheter for artrose.

\section{Till Uhlig}

Revmatologisk avdeling

Diakonhjemmet Sykehus 